\title{
Analysis of Childhood Mortality in Emergency Department
}

\author{
Acil Servisteki Çocukluk Çağı Ölümlerinin Analizi
}

\author{
- Serkan Doğan, ๑ Esin Aldemir*, • Utku Murat Kalafat, • Özgü Hançerli*, \\ ๑ Merih Çetinkaya*, ๑ Başar Cander \\ University of Health Sciences, Kanuni Sultan Süleyman Training and Research Hospital, Clinic of Emergency Medicine, Istanbul, Turkey \\ *University of Health Sciences, Kanuni Sultan Süleyman Training and Research Hospital, Clinic of Pediatrics, İstanbul, Turkey
}

\section{Abstract}

Aim: The aim of the present study was to analyze the mortality rate, demographic characteristics and cause of death in pediatric patients who were referred to our emergency department.

Methods: Patients aged 0-18 years with or without arrest within 24 hours of referral, who died due to any reason in the adult and pediatric emergency departments between January, 1, 2016 and June, 31, 2018, were enrolled and the files were reviewed retrospectively.

Results: A total of 82 children, 39 girls (47.6\%) and 43 (52.4\%) boys-were included in the study. The average age of the children was $66.96 \pm 74.61$ months (0.03-204 months). In consideration of the seasons, the majority of child deaths in the emergency department occurred during the winter months (35.4\%). Excluding the causes other than trauma, the most common reason for arrest was cardiac (39.3\%) and respiratory $(36.1 \%)$ diseases. It was detected that the majority of patients died within a few hours of admission to the emergency department (59.8\%).

Conclusion: Since most deaths occur within the first 4 hours of admission to pediatric emergency room, childhood cardiovascular and respiratory system diseases require careful evaluation.

Keywords: Emergency department referral, childhood, mortality, pediatric emergency department
Öz

Amaç: Bu çalışmanın amacı; acil servise başvuran çocukluk çağı yaş grubundaki ölüm oranları, demografik özellikleri ve altta yatan nedenleri incelemektir.

Yöntemler: Bu çalışmada, erişkin ve çocuk acil servislerine 01.01.2016-31.06.2018 tarihleri arasında gelişinde arrest olan veya olmayan, başvurunun ilk 24 saatinde acil serviste herhangi bir nedenle ölen 0-18 yaş aralığındaki hastalar alınarak, dosyaları retrospektif olarak incelendi.

Bulgular: Çalışmamıza toplam 82 çocuk alınmış olup, 39'u kız $(\% 47,6) 43^{\prime} u ̈ ~(\% 52,4)$ erkek idi. Çocukların ortalama yaşı $66,96 \pm 74,61$ ay (sını; 0.03-204 ay) olarak saptandı. Mevsimsel olarak incelendiğinde acil serviste çocuk ölümlerinin en yüksek kış mevsiminde $(\% 35,4)$ olduğu görüldü. Travma dışı nedenlerle arrest olan olgulardaki en sık nedenlerin kardiyak $(\% 39,3)$ ve solunumsal hastalıklar $(\% 36,1)$ olduğu görüldü. Olguların en sık acil servis başvurularından ilk bir saat içinde kaybedildiği $(\% 59,8)$ tespit edildi.

Sonuç: Mortalitesi yüksek seyreden çocukluk çağı kardiyovasküler ve solunum sistemi hastalıkları için çocuk acil servisinde dikkatli olunmalı, ölümlerin sıklıkla başvuru sırasında ve ilk 4 saatte geliştiğinin sağlık çalışanları tarafından bilinmesi önemlidir.

Anahtar Sözcükler: Acil servis başvuru, çocukluk çağı, mortalite, çocuk acil bölümü
Address for Correspondence/Yazışma Adresi: Serkan Doğan, University of Health Sciences, Kanuni Sultan Süleyman Training and Research Hospital, Clinic of Emergency Medicine, istanbul, Turkey

Phone: +90 2124041500 E-mail: sercem2003@hotmail.com ORCID: orcid.org/0000-0001-8923-2489

Received/Geliş Tarihi: 31 January 2019 Accepted/Kabul Tarihi: 16 April 2019
${ }^{\circ}$ Copyright 2019 by The Medical Bulletin of istanbul Haseki Training and Research Hospital The Medical Bulletin of Haseki published by Galenos Yayinevi. ${ }^{9}$ Telif Hakkı 2019 istanbul Haseki Eğitim ve Araștırma Hastanesi Haseki Tıp Bülteni, Galenos Yayınevi tarafından yayınlanmıștır. 


\section{Introduction}

Childhood is a period of human life affected by socioeconomic, cultural and environmental factors. Children die or become disabled due to predictable and preventable causes with varying incidence rates according to the country even to the region (1). It has been reported that $2.7 \%$ of 607 children died from natural causes whereas $96 \%$ of the deaths were due to accidents which were preventable (2). Although the incidence of natural death during childhood decreases due to reduction of possible causes, the number cases of death caused by accidents has increased recently (3). The World Health Organization (WHO) reported that the number deaths under 5 years of age were more than 5.6 million (4) whereas adolescence deaths were more than 1.2 million (5). Improvements in educational and awareness level as well as developments in healthcare have caused a gradual decrease in childhood mortality rates (6). Recognition of the rates and causes of death is an indicator reflecting healthcare status of the community; these are important to plan the services in both protective and therapeutic medicine prospectively (7). There is a wide ranging reasons for pediatric emergency admissions. Pediatric emergency cases consist of $25 \%$ to $30 \%$ of all emergency department referrals. Approximately $60 \%$ of pediatric referrals are real emergency cases. More than $80 \%$ of causes for child deaths are diseases in this referral group (8).

The aim of the present study was to investigate pediatric mortality rates, underlying causes of deathand demographic characteristics of pediatric patients referred to our pediatric and adult emergency departments; and to determine further precautions and strategies to reduce death rates.

\section{Methods}

Patients aged 0-18 years with and without arrest within 24 hours of referral, who died due to any reason in the pediatric and adult emergency department sat our hospital between January 1, 2016 and June, 21, 2018, were included and the files of the patients were retrospectively analyzed by reviewing the Hospital Information Management System (HIMS) following obtaining ethics committee approval (KAEK/2018.10.31).

Age, gender, referral date and time, existence of arrest, cause for referral, time of death within the first 24 hours, the time elapsed between admission and death and the cost of services in the emergency department were recorded.

Those who were referred due to trauma were divided into two groups: blunt and penetrating trauma. Blunt trauma cases were sub-grouped as in-vehicle traffic accident, extravehicular traffic accident, falling from high, falls on the same level and battery. Penetrating trauma cases were sub-grouped as injury by sharp objects and firearm injury. Non-traumatic causes were sub-grouped as metabolic diseases, central nervous system diseases, respiratory diseases, cardiac diseases, gastrointestinal diseases and intoxications.

Data of the patients were recorded in a case data form and analyzed by SPSS for Windows 22.0 program. Categorical variables were expressed in number and percent whereas numeric variables were demonstrated by mean \pm standard deviation. Quantitative variables without normal distribution had the Mann-Whitney $U$ test applied for statistical assessment. The Pearson chi-square test and Fisher's exact test were used for comparison of qualitative data. The statistical significance level was accepted as $p<0.05$ within a confidence interval of $95 \%$.

\section{Results}

A total 82 children -39 girls (47.6\%) and 43 (52.4\%) boys-were included in the study. The average age of the children was $66.96 \pm 74.61$ months (range $=0.03-$ 204 months). The majority of deaths in the emergency department occurred in February by $14.6 \%(n=12)$ and January by $13.4 \%(n=11)$. In consideration of the seasons, child deaths in the emergency department occurred most frequently in the winter months (35.4\%) followed by spring $(25.6 \%)$, summer $(24.4 \%)$ and fall $(14.6 \%)$. The referral time was between 08.00 a.m. and 3:59 p.m. in $39 \%(n=32)$ of the cases, between 4:00 p.m. and 11:59 p.m. in 35.4\% $(n=29)$; and between 12:00 a.m. and 07:59 a.m. in $25.6 \%(n=21) .68 .3 \% \quad(n=56)$ of patients were referred by the emergency medical service and $31.7 \%$ $(n=26)$ of them presented to the emergency department through their own means.

Fifty-seven (69.5\%) cases were taken with arrest whereas 25 (30.5\%) cases developed arrest during follow-up in the emergency department. Twenty one $(24.6 \%)$ cases were referred because of trauma and 61 (74.4\%) due to non-traumatic reasons. Among patients who were referred because of trauma, $90.5 \%(n=19)$ had blunt trauma and $9.5 \%(n=2)$ had penetrating trauma. The most common causes of blunt trauma were falls (57.9\%) and extravehicular traffic accident (31.6\%). Both patients $(10.5 \%)$ with blunt trauma were referred due to trauma because of getting trapped under a television. The cases with penetrating trauma were divided equally as sharp object injury (50\%) and firearm injury (50\%). The most common reasons for arrest due to non- traumatic causes were cardiac (39.3\%) and respiratory (36.1\%) diseases followed by central nervous system diseases $(13.1 \%)$, metabolic diseases $(8.2 \%)$, gastrointestinal system diseases (1.6\%) and intoxications (1.6\%). It was 
found that $59.8 \%$ of patients died within the first hour of emergency department admission, $20.7 \%$ within 1 to 3 hours and $19.5 \%$ within 3 to 6 hours after admission (Table 1).

\section{Discussion}

The pediatrics and adult emergency departments of our hospital have the highest admission rate in our country. We detected that the majority of child deaths were associated with non-traumatic causes including respiratory and cardiac diseases and occurred during winter; and trauma created a risk for mortality during the summer. Non-traumatic causes for mortality were detected to be more common in the pre-school age group.

The risk of injury or death in the emergency department due to different causes in children is higher than in adults (9). There are wide ranging reasons for pediatric emergency department admissions including trauma and non-traumatic causes; a significant part of referrals (80\%) is real emergency cases (8). A previous study conducted in the United Kingdom reported that $94.7 \%$ of childhood

\begin{tabular}{|c|c|c|}
\hline & & n (\%) \\
\hline \multirow[b]{2}{*}{ Referral state } & Arrest state & $57(69.5)$ \\
\hline & $\begin{array}{l}\text { Arrest in the emergency } \\
\text { department }\end{array}$ & $25(30.5)$ \\
\hline \multirow[t]{2}{*}{ Reason for referral } & Trauma & $21(25.6)$ \\
\hline & Non-traumatic & $61(74.4)$ \\
\hline \multirow{2}{*}{$\begin{array}{l}\text { Trauma type } \\
(n=21)\end{array}$} & Blunt & $19(90.5)$ \\
\hline & Penetrating & $2(9.5)$ \\
\hline \multirow{3}{*}{$\begin{array}{l}\text { Blunt Trauma type } \\
(n=19)\end{array}$} & Extravehicular traffic accident & $6(31.6)$ \\
\hline & Falling & $11(57.9)$ \\
\hline & $\begin{array}{l}\text { Getting trapped under a } \\
\text { television }\end{array}$ & $2(10.5)$ \\
\hline \multirow{2}{*}{$\begin{array}{l}\text { Penetrating } \\
\text { Trauma type }(n=2)\end{array}$} & Sharp Object Injury & $1(50.0)$ \\
\hline & Firearm Injury & $1(50.0)$ \\
\hline \multirow[t]{3}{*}{$\begin{array}{l}\text { Non-traumatic } \\
\text { cause }(n=61)\end{array}$} & $\begin{array}{l}\text { Cardiac diseases } \\
\text { Respiratory diseases } \\
\text { central nervous system diseases } \\
\text { metabolic diseases }\end{array}$ & $\begin{array}{l}24(39.3) \\
22(36.1) \\
8(13.1) \\
5(8.2)\end{array}$ \\
\hline & Gastrointestinal diseases & $1(1.6)$ \\
\hline & Intoxications & $1(1.6)$ \\
\hline \multirow{3}{*}{$\begin{array}{l}\text { Time of death } \\
\text { after admission }\end{array}$} & 0-1 hour & $49(59.8)$ \\
\hline & $1-3$ hours & $17(20.7)$ \\
\hline & 3-6 hours & $16(19.5)$ \\
\hline \multicolumn{3}{|c|}{$\begin{array}{l}n=\text { Number } \\
\text { The majority of patients with trauma and non-traumatic conditions were referred } \\
\text { during the winter months, thus there was not any statistically significant difference } \\
\text { ( } p=0.050) \text {. It was detected that the patients admitted because of trauma died } \\
\text { within } 1 \text { to } 3 \text { hours following admission, earlier when compared with patients } \\
\text { admitted due to non-traumatic reasons }(p=0.003 ; p<0.01 \text { ) (Table } 2 \text { ) }\end{array}$} \\
\hline
\end{tabular}

deaths were due to non-traumatic causes (10). A study from Pakistan indicated an incidence rate of $86.5 \%$ for deaths due to non-traumatic causes (11). It was detected that $74.4 \%$ of the childhood deaths in the emergency department were associated with non-traumatic causes, which is in line with the literature.

A study conducted on 151 deaths in the pediatric age group in Van reported that $56.3 \%$ of 151 patients were boys and $43.7 \%$ were girls in 2017 (12). Similarly, the mortality rates in boys were $67 \%$ and $54.7 \%$ in studies from Spain and the United Kingdom, respectively $(13,14)$. In line with the literature, $52.4 \%$ of the death cases were boys in the present study. Although, the exact cause is uncertain, boys were detected to have more risk for mortality in the emergency department.

In a previous retrospective study including 204 autopsied patients aged 0-18 years, the most common cause for death was found to be traffic accidents (64.6\%) (15). In a study by Sogut et al. (16), traffic accidents and falls were detected to be the most common cause of hospital admissions due to trauma $(38.7 \%$ and $36.8 \%$, respectively) (16). In the present study, the most common cause of trauma was falls $(57.9 \%)$ followed by extravehicular traffic accident (31.6\%). The difference when compared with the literature was associated with the fact that our hospital was located in an area in which falls was the most common cause for trauma and the cases enrolled included forensic and natural deaths. Although

\begin{tabular}{|c|c|c|c|c|}
\hline & & \multicolumn{2}{|c|}{ Reason for Referral } & \multirow{2}{*}{\begin{tabular}{|l|}
$\begin{array}{l}\text { Test } \\
\text { value }\end{array}$ \\
$\mathbf{p}$ \\
\end{tabular}} \\
\hline & & $\begin{array}{l}\text { Trauma } \\
(\mathrm{n}=21), \mathrm{n} \\
(\%)\end{array}$ & $\begin{array}{l}\text { Non- } \\
\text { traumatic } \\
(\mathrm{n}=61), \mathrm{n} \\
(\%)\end{array}$ & \\
\hline \multirow[t]{2}{*}{ Gender } & Girl & $7(33.3)$ & $32(52.5)$ & $\chi^{2: 2.291}$ \\
\hline & Male & $14(66.7)$ & $29(47.5)$ & ${ }^{a} 0.130$ \\
\hline \multirow[t]{4}{*}{ Date of referral } & Winter & $3(14.3)$ & $26(42.6)$ & $\chi^{2}: 7.624$ \\
\hline & Spring & $6(28.6)$ & $15(24.6)$ & $a 0.050 *$ \\
\hline & Summer & $9(42.9)$ & $11(18.0)$ & - \\
\hline & Fall & $3(14.3)$ & $9(14.8)$ & - \\
\hline \multirow{3}{*}{$\begin{array}{l}\text { Time of Death } \\
\text { after Admission }\end{array}$} & 0-1 hour & $8(38.1)$ & $41(67.2)$ & $\chi^{2}: 10.999$ \\
\hline & 1-3 Hours & $10(47.6)$ & $7(11.5)$ & $b_{0.004 * *}$ \\
\hline & 3-6 Hours & $3(14.3)$ & $13(21.3)$ & - \\
\hline \multicolumn{5}{|c|}{$\begin{array}{l}\text { aPearson's chi-square test, bFisher-Freeman-Halton exact test, }{ }^{* *} p<0.01 \\
\text { The number of patients with arrest who were taken by emergency ambulance } \\
\text { services ( } 112) \text { was found to be higher than that of those who developed arrest } \\
\text { during follow-up in the emergency department }(p=0.036 ; p<0.05) \text {. The incidence } \\
\text { of death in patients who had arrest within } 0 \text { to } 1 \text { hour following admission } \\
\text { were significantly higher than in those in other periods }(p=0.001 ; p<0.01 \text { ). } \\
\text { The incidence of death in patients who developed arrest in the emergency } \\
\text { department within } 1 \text { to } 3 \text { hours and } 3 \text { to } 6 \text { hours were found to be significantly } \\
\text { higher than within } 0-1 \text { hours }(p=0.012 ; p=0.001 ; p<0.05 \text { ) (Table } 3 \text { ) }\end{array}$} \\
\hline
\end{tabular}


causes of trauma may differ, trauma was considered to be related with emergency department mortality among children died of non-traumatic causes.

Many studies in the literature reported higher rates of death due to trauma (especially in extravehicular traffic accidents) in children below 16 years of age $(17,18)$. In a study by Demir et al. (12), traffic accidents were found to be the most common cause of death due to trauma (27.8\%). In our study, we observed that traumarelated mortality was common in pre-school children and adolescents. It is considered that the increase in trauma during pre-school age was due to incomplete development of instincts to protect from dangers and,

\begin{tabular}{|c|c|c|c|c|}
\hline & & \multicolumn{2}{|c|}{ Condition at admission } & \multirow{2}{*}{$\begin{array}{l}\text { Test value } \\
\mathbf{p}\end{array}$} \\
\hline & & $\begin{array}{l}\text { Arrest } \\
\text { State } \\
(\mathrm{n}=57) \\
\mathrm{n}(\%)\end{array}$ & $\begin{array}{l}\text { Arrest in the } \\
\text { emergency } \\
\text { department } \\
(n=25), n(\%)\end{array}$ & \\
\hline \multirow[t]{2}{*}{$\begin{array}{l}\text { Admission } \\
\text { Type }\end{array}$} & $\begin{array}{l}\text { Emergency } \\
\text { ambulance } \\
(112)\end{array}$ & $43(75.4)$ & $13(52.0)$ & $\chi^{2}: 4.409$ \\
\hline & $\begin{array}{l}\text { Herself/ } \\
\text { himself }\end{array}$ & $14(24.6)$ & $12(48.0)$ & a $0.036 *$ \\
\hline \multirow{3}{*}{$\begin{array}{l}\text { Time of } \\
\text { Death after } \\
\text { Admission }\end{array}$} & $0-1$ hours & $46(80.7)$ & $3(12.0)$ & $\chi^{2}: 35.126$ \\
\hline & $1-3$ hours & $7(12.3)$ & $10(40.0)$ & $a 0.001 * *$ \\
\hline & 3-6 hours & $4(7.0)$ & $12(48.0)$ & - \\
\hline \multicolumn{5}{|c|}{$\begin{array}{l}\text { apearson chi-square test, }{ }^{*} p<0.05,{ }^{* *} p<0.01 \\
\text { The review of distribution according to the age groups revealed a statistically } \\
\text { significant difference between traumatic and non-traumatic patients }(p<0.01) \text {. } \\
\text { The death related with trauma was significantly higher in the pre-school age and } \\
\text { adolescence than in others }(p=0.008) \text { (Table } 4 \text { ). }\end{array}$} \\
\hline
\end{tabular}

having much time outside the house and school may play a role for trauma.

The World Health Organization (WHO) reported the causes of death during childhood as follows; prematurity (17\%), lower respiratory tract infection (15\%), birth asphyxia (11\%), diarrhea (9\%), congenital abnormality (7\%), newborn sepsis (7\%), traumas $(6 \%)$ and other causes (17\%) (5). A study including patients whose death was certified in 18 pediatric emergency departments in Spain between 2008 and 2013 reported that the most common causes of death were related to a previous disease in $24.5 \%$, sudden infant death syndrome in $20.7 \%$ and trauma in $18.8 \%$ of 53 children (13). A study from the United Kingdom in 2018 reported the causes of death as chromosomal-genetic-congenital abnormalities by $50.5 \%$, malignancies by $10.5 \%$, infections by $10.5 \%$, acute surgical problems by $9.5 \%$, traumas by $5.3 \%$, and perinatalneonatal problems by $2.1 \%$ (14). A previous study carried out in our country detected the most common cause as follows: respiratory system diseases $-42.8 \%$, cardiovascular system diseases $-28.5 \%$ and prematurity and septic shock $-14.2 \%$ (15). In line with the literature, the most common non-traumatic causes of death are cardiac diseases (39.3\%) and respiratory diseases (36.1\%); and cardiac and respiratory diseases are risky in terms of mortality during childhood; therefore, these may be responsible from childhood deaths in emergency departments.

It was determined in another study that majority of patients (22\%) died after cardiac surgery; $63 \%$ of the children had an underlying chronic disease; and $61 \%$ of the death cases appeared between 0 and 4 years of age

Table 4. Evaluation according to age groups

\begin{tabular}{|c|c|c|c|c|c|c|}
\hline & \multicolumn{5}{|c|}{ Age groups } & \multirow[b]{2}{*}{$\mathrm{b}_{\mathrm{p}}$} \\
\hline & $\begin{array}{l}\text { Newborn, } \\
\text { n (\%) }\end{array}$ & $\begin{array}{l}\text { Infancy, } \mathbf{n} \\
\text { (\%) }\end{array}$ & $\begin{array}{l}\text { Pre-school } \\
\text { age, n (\%) }\end{array}$ & $\begin{array}{l}\text { School age, } \\
\text { n (\%) }\end{array}$ & $\begin{array}{l}\text { Adolescence, } \\
\mathrm{n}(\%)\end{array}$ & \\
\hline \multicolumn{7}{|l|}{ Reason for referral } \\
\hline Trauma & 0 & $3(10.0)$ & $9(45.0)$ & $1(10.0)$ & $8(44.4)$ & \multirow{2}{*}{$0.008^{* *}$} \\
\hline Non-traumatic & $4(100)$ & $27(90.0)$ & $11(55.0)$ & $9(90.0)$ & $10(55.6)$ & \\
\hline \multicolumn{7}{|l|}{ Trauma type $(n=21)$} \\
\hline Blunt & 0 & $3(100)$ & $9(100)$ & $1(100)$ & $6(75.0)$ & \multirow{2}{*}{0.486} \\
\hline Penetrating & 0 & 0 & 0 & 0 & $2(25.0)$ & \\
\hline \multicolumn{7}{|l|}{ Non-traumatic cause $(n=61)$} \\
\hline Metabolic disease & 0 & $2(7.4)$ & $2(18.2)$ & 0 & $1(10.0)$ & \multirow{6}{*}{0.182} \\
\hline Central nervous system disease & 0 & $1(3.7)$ & $4(36.4)$ & $2(22.2)$ & $1(10.0)$ & \\
\hline Respiratory diseases & $1(25.0)$ & $13(48.1)$ & $13(27.3)$ & $3(33.3)$ & $2(20.0)$ & \\
\hline Cardiac diseases & $3(75.0)$ & $11(40.7)$ & $2(18.2)$ & $4(44.4)$ & $4(40.0)$ & \\
\hline Gastrointestinal diseases & 0 & 0 & 0 & 0 & $1(10.0)$ & \\
\hline Intoxications & 0 & 0 & 0 & 0 & $1(10.0)$ & \\
\hline
\end{tabular}


whereas $89.5 \%$ of such patients were below 1 year of age (14). Kafadar et al. (15) reported that an underlying chronic disease was a risk factor in majority of deaths. It was detected in the present study, in line with the literature, that concomitant chronic diseases might be responsible for childhood mortality in our emergency department.

Studies conducted in our country revealed that the incidence of death due to trauma was higher in the summer season when compared with other seasons; and trauma-associated deaths occurred more commonly in school children and adolescents $(12,15)$. Another study detected that $78 \%$ of the childhood death cases due to trauma appeared during the spring and summer seasons $(17,18)$. The present study detected similar findings with the literature. Traumaassociated deaths were more common in the summer whereas non-traumatic deaths were more during the winter. It is considered that the incidence of trauma increases during the summer since children have time outdoor and trauma may constitute a risk for childhood mortality during the summer. The abovementioned findings suggest that the difference in the etiology of childhood mortality in the emergency department depends on the season; awareness of emergency department physicians may facilitate diagnosis and treatment.

A previous study reported that $58 \%$ of pediatric patients with trauma died before arriving at the hospital, whereas $42 \%$ died after arrival; and $72.2 \%$ of those who arrived at the hospital died within the first 4 hours (19). In line with the literature, $87.5 \%$ of our cases who were taken to the emergency department due to trauma died within the first 3 hours of admission. The first hours bear a higher risk for mortality for pediatric patients admitted to emergency department due to trauma.

\section{Conclusion}

The majority of reasons of childhood death in emergency department include non-traumatic causes. Respiratory and cardiac diseases during the winter months as well as trauma during the summer bear a risk for childhood mortality in emergency departments. The healthcare staff in the pediatric emergency department should be aware of cardiovascular and respiratory diseases which progress with higher mortality during childhood and the patient history should be obtained from the parents. Since childhood deaths occur within the first 4 hours, this should alert the physicians and, children under risk should be monitored closely for 4 hours at least. Furthermore, it is considered that death rates may be reduced by taking precautions for the prevention of trauma which is one of preventable and reducible death causes. Awareness of the physicians in pediatric and adult emergency departments about the risk factors, close monitoring for the first 4 hours as well as adequate diagnosis and treatment may allow reducingthe incidence of such deaths.

\section{Authorship Contributions}

Concept: S.D., U.M.K., Ö.H., B.C. Design: S.D., E.A., M.Ç., U.M.K. Data Collection or Processing: S.D., E.A., Ö.H. Analysis or Interpretation: E.A., Ö.H., M.Ç., B.C. Literature Search: M.Ç., B.C. Writing: S.D., E.A., U.M.K., M.Ç.

Conflict of Interest: No conflict of interest was declared by the authors.

Financial Disclosure: The authors declared that this study received no financial support.

\section{References}

1. Arslan MM, Kar H, Çekin N, et al. Evaluation of Medicolegal Autopsy Results of Child Hood Deaths in 1997-2001 at Adana. The Bulletin of Legal Medicine 2004;9:37-42.

2. Saunders CO, Forjuoh SN, West P, et al. Child death reviews: a gold mine for injury prevention and control. Injury prevention 1999;5:276-79.

3. Savran B, Yarış F, Çan G, et al. Forensic Death Cases in Childhood in Trabzon J ForMed 2003;17:28-32.

4. United Nations Inter-Agency Groupfor Child Mortality Estimates (UN IGME). Levels and Trends in Child Mortality: Report 2017. New York: United Nations Children's Fund. 5. WHO. Global health. https://www.unicef.org/publications/ index_101071.html

5. WHO. Global health estimates 2015: deaths by cause, age, sex, by country and by region, 2000-2015. Geneva: World Health Organization; 2016. https://www.who.int/healthinfo/ global_burden_disease/estimates/en/index1.html

6. Levels \& Trends in Child Mortality. Estimates developed by the UN inter-agency group for child mortality estimation. WHO/ UNICEF/UN Report 2013. Available at:http://www.who.int/ maternal_child_adolescent/documents/levelstrendschild_ mortality 2013.pdf. (cited: 17 January 2017).

7. Inanıcı M, Birgen N. The Evaluation of Medicolegal Aspects of the Child Death Aging From 0 to 5 Years. The Bulletin of Legal Medicine 2001;6:70-5.

8. Çağlar S, Yıldız S. General Approaches in Pediatric Emergency: Epidemiology. Turkiye Klinikleri Journal of Pediatric NursSpecial Topics 2016;2:5-9.

9. Byard RW. Accidental childhood death and the role of the pathologist. Pediatric and Developmental Pathology 2000;3:405-18.

10. Magnus DS, Schindler MB, Marlow RD, et al. A Service evaluation of a hospital child death review process to elucidate understanding of contributory factors to child mortality and inform practice in the English National Health Service. BMJ Open 2018;8:e015802. 
11. Razzak JA, Khan UR, Zia N, et al. A child an hour: burden of injury deaths among children under 5 in Pakistan. Arch Dis Child 2013;98:867-71.

12. Demir $U$, Aşırdizer $M$, Etli $Y$, et al. Analysis of accidental deaths of children under five years of age. J For Med 2017;31:17-25.

13. Lopez E, Udaondo J, Olabarri M, et al. Mortality Group of RISEUP-SPERG (Reddelnvestigación de la SociedadEspañola de Urgencias de Pediatría-Spanish Pediatric Emergency Research Group). Mortality in Spanish pediatric emergency departments: a 5-year multicenter survey. Eur J Emerg Med 2017;24:392-7.

14. Magnus DS, Schindler MB, Marlow RD, et al. A Service evaluation of a hospital child death review process to elucidate understanding of contributory factors to child mortality and inform practice in the English National Health Service. BMJ Open 2018;8:e015802.
15. Kafadar H. Evaluatingthe 0-18 Years Old Cases Autopsied between 2001-2007 in Elazığ. FiratMed J 2009;14:111-4.

16. Sogut O, Sayhan MB, Gokdemir MT, et al. Analysis of Hospital Mortality and Epidemiology in Trauma Patients: A MultiCenter Study, J Curr Surg 2011;1:19-24.

17. Tokdemir M, Kafadar H, Turkoglu A, et al. Comparison of the severity of traumatic brain injuries in pedestrians and occupants of motor vehicles admitted to firat health center: A five-year series in an Eastern Turkish city. Med Sci Monit 2009;15:PI1-4.

18. Atkins RM, Turner WH, Duthie RB, et al. Injuries to pedestrians in road traffic accidents. BrMed J 1988;297:1431-4.

19. Søreide K, Krüger $A J$, Ellingsen $C L$, et al. Pediatric trauma deaths are predominated by severe head injuries during spring and summer. Scand J Trauma Resusc Emerg Med 2009;17:3. 